\title{
Analysis of Career Maturity on High School Students
}

\author{
Yanuari Srianturi* \\ Guidance and Counseling School of \\ Postgraduate Studies \\ Indonesia University of Education \\ Bandung, Indonesia \\ yanuaris17@yahoo.com.*
}

\author{
Mamat Supriatna \\ Guidance and Counseling School of \\ Postgraduate Studies \\ Indonesia University of Education \\ Bandung, Indonesia \\ ma2t.supri@upi.edu
}

\begin{abstract}
This article aims to determine the career maturity profile of high school students based on the results of a review of the theories of John Milton Dillard, Donald Edwin Super, John Lewis Holland and the results of previous relevant research on career maturity. Career maturity is needed by teenagers to be able to choose and prepare themselves to enter the career world well. Career maturity should be owned by high school students by making the right career choices to continue further study or enter the workforce. This research employed survey method. The research instrument trials were conducted on 305 students of class XI at SMA N 6 Bandung. Instrument trials include testing the validity and reliability testing. The data needed in this study is the career maturity profile of class XI high school students. To obtain student career maturity profile data used an instrument of student career maturity that is made based on three aspects, namely cognitive aspects, affective aspects, and psychomotor aspects. The results of this study indicate that the general profile of career maturity of class XI high school students is in the quite capable category as seen from the cognitive, affective and psychomotor aspects, meaning that the majority of students have knowledge, attitudes and skills related to career maturity that are not yet optimal. The results showed that the aspect that had the highest percentage was the cognitive aspect, while the psychomotor aspect had the lowest percentage. Indicators on the psychomotor aspects are building motivation, operating facilities and infrastructure and managing planning.
\end{abstract}

Keywords - career maturity, career development

\section{INTRODUCTION}

Career maturity is needed by teenagers to be able to choose and prepare themselves to enter the career world well. Super believes that the success and readiness of adolescents to fulfill organized tasks contained in each stage of career development is called career maturity [1]. According to Super [2] explained that high school students belong to the exploration stage. At this stage the task of adolescent career development is to develop a realistic selfconcept, learn more about broad opportunities and start choosing majors in college. Career maturity should be owned by high school students, who have made career choices to continue their studies or enter the workforce. The problem of career maturity can cause mistakes in making career decisions for high school students. In fact, there are high school students who choose an education major without considering their abilities, talents, interests, and personality. They tend to follow the choices of parents, friends, on the basis of job popularity or identification of jobs suggested by parents. Seligman [3] emphasizes the importance of career maturity for life such as increasing competence, career goals and realizing careers related to independent attitude, careful planning, commitment, motivation and self-efficacy. During high school students should have started gathering information about themselves and the world of work through an exploration process with the aim of crystallizing and making wise career choices. High school students especially in class XI should be able to direct their ideals and learn to make career aspirations based on their interests and abilities. Super [4] that one's career maturity has dimensions or factors that influence it including career planning, career exploration, knowledge about career decision making, information about the world of work, knowledge about work groups that preferred and the realization of career decisions. According to the Super theory [2] aspects of career maturity consist of 3 namely covering aspects of self-knowledge, attitudes and skills.

The results of the Central Statistics Agency survey data related to unemployment based on the highest education completed as of February 2017 revealed that high school graduates ranked highest against the unemployment rate of $1,552,894$ people. This is because high school graduates have not mastered attitudes and skills about the world of work so they are less able to continue to tertiary level. This fact serves as a guideline that the importance of career guidance in every line of education is so that in the future it can minimize the high unemployment rate in Indonesia. Many high school graduates in Indonesia are not in accordance with the qualifications needed by the world of work or do not have qualified work experience, so it requires a direction such as training or internships.

Based on the results of observations by researchers when conducting internship activities for approximately two months at SMA N 6 Bandung obtained information that most students of class XI do not have optimal career maturity marked by not having maximum career planning, they still experience doubts and confusion in determining work what will be lived later. Most students of class XI do not have a clear picture of the future. Students lack 
comprehensive information such as identifying work groups, specific college majors information and how strategies for making career decisions that are relevant to their talents and interests. Saifuddin's findings [5] show that there are still many high school students who have low career maturity because of a lack of insight into career planning information, lack of career guidance from teachers and parents, environmental influences and peers and family environment. Career maturity is one aspect of the whole process of individual development and choices concerning future positions that go in harmony with career development. The problem of career maturity is a problem of the future of adolescents, so it must be prepared as well as possible in terms of planning and making a career decision. In an effort to develop student career maturity, career guidance strategies or programs are needed that are designed in accordance with the needs of students.

\section{METHODS}

This research employed survey method. The study was conducted at SMA N 6 Bandung. The data needed in this study is the career maturity profile of high school students. To obtain student career maturity profile data used career maturity instruments. The instrument test was conducted on 305 students of class XI at SMA N 6 Bandung. The career maturity instrument used is an instrument developed based on the procedure: 1) formulation of the conceptual definition of career maturity based on the opinions of experts; 2) formulation of operational definitions of career maturity; 3) formulation of instrument of career maturity; 4) scoring and interpretation guidelines; 5) testing the judgment of the instrument statement; 6) instrument results. Career maturity instruments are arranged based on 3 career maturity theorists, [6], Donald Edwin Super [2] and John Holland [7]. Career maturity instrument consists of cognitive aspects, affective aspects and psychomotor aspects. The cognitive aspect consists of indicators exploring self-potential, considering values and inferring. Affective aspect consists of indicators judging, manage and appreciate. Psychomotor aspect consists of aspects of building motivation, operating facilities and planning. The instrument used in this study is the linkert scale. The instrument validity test was performed using the product moment formula with a significance of 5\%. After revisions and improvements provided by the guidance and counseling experts, the instruments used as research were 43 items.

\section{RESULT AND DISCUSSION}

Result

The career maturity profile of High School students is revealed through the career maturity instrument. The instrument was distributed to 305 students of class XI at SMA N 6 Bandung in the academic year 2019/2020. The research findings show that the greatest percentage of career maturity of class XI students of SMA N 6 Bandung in the academic year 2019/2020 is in the quite capable category, which is $72 \%$ or as many as 213 students. This means that the majority of students have the knowledge, attitudes and skills needed related to career maturity in the medium category with marked achievements in the cognitive, affective and psychomotor aspects. An overview of the general profile of career maturity of class XI students of SMA N 6 Bandung in the academic year 2019/2020 will be presented in figure 1 below.

\begin{tabular}{|c|c|c|c|}
\hline \multirow{3}{*}{$\begin{array}{r}100 \% \\
0 \%\end{array}$} & \multicolumn{3}{|c|}{ Profile of Career Maturity's Student } \\
\hline & $8 \%$ & $70 \%$ & $22 \%$ \\
\hline & Excellent & Moderate & Poor \\
\hline
\end{tabular}

Fig. 1 Profile of career maturity's student

After describing the profile of career maturity's student of SMA N 6 Bandung, the profile of career maturity of class XI Bandung N 6 Bandung will be presented in terms of every aspect is cognitive aspects, affective aspects and psychomotor aspects. Visually, career maturity profiles on each aspect can be illustrated in figure 2 as follows.

\section{Profile of Aspects Career Maturity's Student}

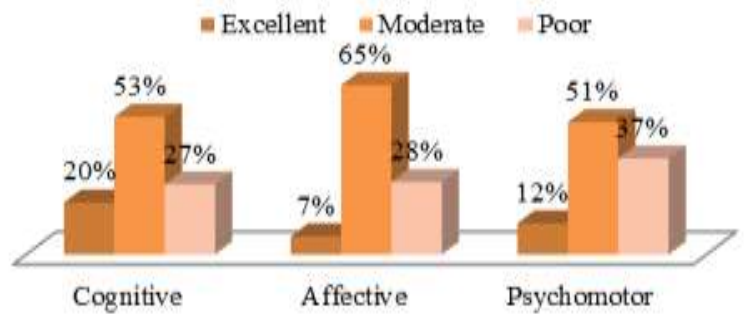

Fig 2. Profile of aspects career maturity's student

In cognitive aspects as many as 161 students are in the category of capable enough with a percentage of $53 \%$. In the affective aspect, the majority of students are in the quite capable category that is equal to $65 \%$ or 198 people. The research findings also reveal the career maturity profile of class XI students of SMA N 6 Bandung in the 2019/2020 school year on each indicator. In the psychomotor aspect, most of the students are in the quite capable category as many as 156 people, with a percentage of $51 \%$. In the category of being able to get by $12 \%$ as many as 37 people then the category of underprivileged as many as $37 \%$ is as many as 113 people. There are three aspects of career maturity, each of which consists of three indicators. Visually the research findings of indicators of career maturity in each aspect are illustrated in figure 2, figure 3 and figure 4 as follows. 


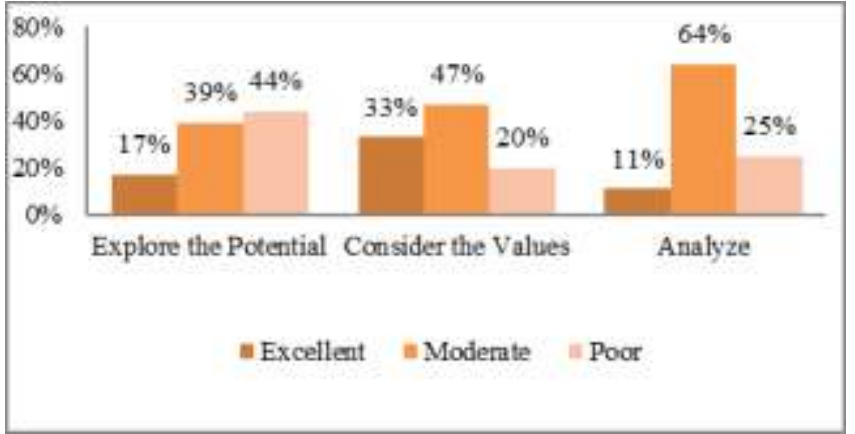

Fig 3. Career maturity profile of students in cognitive aspects

The indicator that has the highest percentage of the underprivileged is the indicator of exploring self potential means that students in SMA N 6 Bandung are still less able to fully involve themselves in exploring their potential, in the indicator of exploring self potential there are only $17 \%$ of students who are able to explore their self potential as many as 52 student people. Teenagers can search for career related information that they are interested in from various sources, such as from family and school. In addition, what is needed by adolescents in achieving career maturity is knowing their potential so that adolescents are able to make appropriate career choices [8]. Followed by as many as 61 students belonging to the category of underprivileged on indicators considering the values in planning a career, meaning students understand about the values and norms that develop in society related to career exploration, but in fact students have not been able to apply it in everyday life. Dillard [9] argues that a person's values can affect his career performance. When someone is active in accordance with their values, he will feel happy and happy doing his activities.

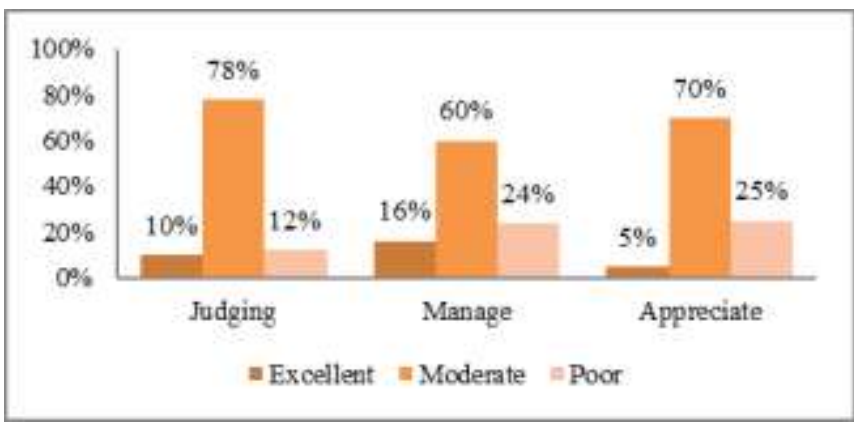

Fig 4. Career maturity profile of students in affective aspects

Figure 4 illustrates the profile of career maturity indicators of XI class X SMA N 6 Bandung students on affective aspects. The effective aspect of career maturity consists of indicators assessing, managing and living. Of the three indicators there is one indicator that has the category of being able to namely the indicator rate of $43 \%$ means that as many as 131 students have good abilities in assessing accurately and precisely about themselves and career exploration as many as 61 students or by $24 \%$ who have a category of underprivileged indicator rate. The majority of students are quite capable in managing career planning well, this is by obtaining $60 \%$ of data in the category of quite capable in managing indicators. In the living indicator only
$5 \%$ or 15 students are included in the able category, but $70 \%$ or 213 students in the quite capable category are obtained. If we look at the percentage acquisition, it can be interpreted that there is a difference in the percentage level that is not too far in the category of underprivileged in the affective aspects. The findings of the study showed that in general students in the category of underprivileged in all indicators were in the range of $20 \%-25 \%$, meaning that as many as 61 students to 76 students had not been able to master optimally on the affective aspects of career maturity.

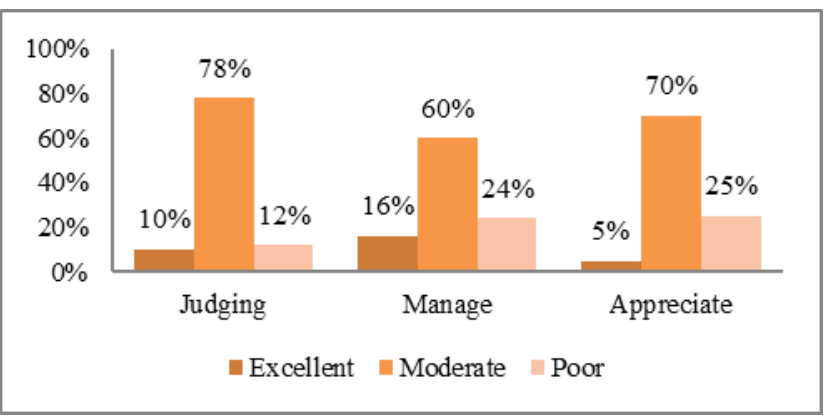

Fig 5. Career maturity profile of students in psychomotor aspects

Figure 5 shows the profile of career maturity indicators on psychomotor aspects. Psychomotor aspects of career maturity consist of three indicators, namely building motivation, operating facilities and infrastructure and managing planning. In the indicator set planning the majority of students are in the category of moderately able with a percentage of $75 \%$, as many as 228 students, only $25 \%$ of students or as many as 76 people belonging to the category of underprivileged in the category of manage planning.

\section{Discussion}

From a total of nine indicators of career maturity there are two indicators of career maturity that are in the category of being able, namely indicators assessing on the affective aspects and indicators of building motivation on psychomotor aspects. The five indicators which the majority are in the category of being quite capable are indicators considering values and indicators analyzing on cognitive aspects then managing indicators and indicators live on affective aspects then indicators operating infrastructure and organizing planning on psychomotor aspects. In the research findings there is one indicator that the majority of students classified as less able, namely the indicator to explore their potential in cognitive aspects with the acquisition of a percentage of $44 \%$ or as many as 134 students. The research findings also reveal the average achievement score of indicators of student career maturity in the range of $58 \%$ $72 \%$ of the ideal score. The highest average score achieved by the indicator assesses $72 \%$ and indicators build motivation by $70 \%$. While the lowest average score is $59 \%$ and the indicator regulates planning by $58 \%$.

According to Dillard, determining career maturity is an individual decision in career decision making that is revealed by the level of consistency in career choices within a certain period [9]. Mastery of skills is very necessary in 
adolescence has begun to be needed [7]. By the time teenagers have started the future in earnest. In future discussions, career interest is often a source of teenage thinking in terms of distinguishing between better and aspired job choices.

Problems in career planning also occur in MAN Wonokromo Bantul students. Student interest in continuing studies is very minimal, overall tend to choose to work. However, when there is a question "where will work and what work" they are still confused, do not have a definite answer, and only rely on limited skills with minimal working knowledge. This is reinforced by Atmaja that in the career planning process individuals will gain knowledge about the potential that exists in themselves which includes skills, interests, knowledge, motivation, and characteristics that are used as a basis in career selection which then continues with determining the stages to be able to achieve a chosen career [10]. In accordance with Holland's theory [7] states that there is a relationship between personality characteristics, the environment and work that allows one to hone skills and abilities so as to achieve career maturity. This phenomenon is reinforced by the findings of a study conducted by Lestari found that career problems of class XI high school students are less able to plan a career due to lack of information and motivation in choosing a career in the future [11].

The findings of the research Juwitaningrum found that the career maturity of students in general in SMK $\mathrm{N} 1$ Bandung has a moderate or quite capable category that is equal to $48 \%$ [12]. However, the findings of this study differ from the results of research conducted by Nurlela finding that the majority of students in SMA PGRI 2 Palembang as much as $65.88 \%$ have career maturity in the underdone category, a small proportion of students $12.94 \%$ have career maturity in the mature category, and the other $21.17 \%$ actually have career maturity in the immature category [10]. The difference in the findings of this study is due to differences in environmental factors and different characteristic factors of each student.

The research conducted by Nurlela was carried out at SMA PGRI 2 Bandung and the research conducted by Lestari was conducted at SMA N 81 Jakarta while the research was conducted at SMA $\mathrm{N} 6$ Bandung. The difference in schools gives an influence on the students' career maturity [13]. This is in line with the opinion of Super [2] explaining that there are several factors that influence the achievement of individual career maturity, namely biosocial factors, such as age and intelligence, environmental factors, namely the level of work of parents, schools, cultural stimulus and family cohesiveness, personality, including self-concept, control focus, special talents, values or norms and life goals. vocational factors, suitability level of aspirations and career expectations, individual achievements. This difference is due to differences in career expectations and strong self-concepts between students of SMK Muhammadiyah Imogiri and SMA N 6 Bandung. As mentioned by Marcia that the characteristics of individuals who experience diffusion identity are individuals who lack a strong self-concept.
Students tend to lack the knowledge shown by the low breadth and depth of information gathered about various alternatives in the formation of identity [14].

John L. Holland formulates personality types in job selection based on an inventory of personalities based on interests. Each type of personality is translated into a theoretical model called the model orientation. This orientation model is a typical family of adjustment behaviors. Every person has a different order of orientation, and this is why everyone has a different style of life. Holland in the Career Typology Theory of Vocational Behavior believes that it is important to establish links or compatibility between individual personality types and specific career choices. The point is career selection and adjustment is a picture of one's personality. Individuals are said to reach maturity in their careers if they already have the readiness to make decisions about their career choices correctly and wisely [15].

The contribution of these influencing factors is also reinforced by Prabowo's findings in 2018 that in general XI grade students of Muhammadiyah Vocational High School Imogiri are in diffusion status, where in this status shows that students are still not optimal in conducting career exploration, and do not yet have career commitment. Students have not sought information about vocational alternatives and have not tried to establish a vocational choice to be made [16]. So that the majority of students have a career maturity that is not yet optimal. This difference is due to differences in career expectations and strong selfconcepts between students of SMK Muhammadiyah Imogiri and SMA N 6 Bandung. As mentioned by Marcia that the characteristics of individuals who experience diffusion identity are individuals who lack strong self-concepts [12]. Students tend to lack in-depth knowledge which is indicated by low in breadth and depth of information gathered about various alternatives in the formation of identity. According to Super [2] self-concept is the result of interactions of innate abilities, physical conditions, role opportunities, and evaluations of whether the role played gets the approval of an older person or superior. In the rhythm of one's life dynamic changes occur and this affects the effort to realize that self-concept.

Career maturity consists of three aspects, namely cognitive aspects, affective aspects and psychomotor aspects. In terms of every aspect, the career maturity profile of students of SMA N 6 Bandung class XI in the academic year 2019/2020 is in the quite capable category. This means that these students have understanding, attitudes and skills that are in the medium category in every aspect so that it has not yet reached optimal career maturity. The profile achievement of career maturity aspects at SMA N 6 Bandung shows that the highest average score of students is in the psychomotor aspect with an average percentage of $70 \%$ of the ideal score. Then followed by affective aspects with an average score of $61 \%$ of the ideal score. While in the cognitive aspect, students get the lowest score with an average score of $60 \%$ of the ideal score. Achievement scores in all indicators of career maturity on the cognitive aspects show a figure of more than $11 \%$. The indicator which has the highest percentage of poor is on the indicator of 
exploring self-potential meaning that students in class XI SMA N Bandung are still unable to fully involve themselves in exploring their potential, in the indicator of exploring self-potential there are only $17 \%$ students who are able to explore their potential namely as much as 52 students. Teenagers can search for career related information that they are interested in from various sources, such as from family and school. In addition, what is needed by adolescents in achieving career maturity is knowing their potential so that adolescents are able to make appropriate career choices [8].

According to the Super theory [2] aspects of career maturity consist of 3 namely covering aspects of selfknowledge, attitudes and skills. This aspect is in accordance with individual career development. (1) Self-knowledge expanded: clear goals after completing education, challenging perceptions of oneself and the environment such as knowing interests and talents, (2) to advance in the fields of education, work and values, be independent and mature and capable in the process decision making, (3) skills include: the ability to group jobs that are of interest and determine challenging ways of achieving self, understanding of values and understanding of career opportunities. This theory led to the concept of work itself. Connect with other people and he needs self-concept by choosing a job, things that suit this person are the most possible self-expression.

John Holland defines that career maturity is a career selection and adjustment based on a description of a person's personality characteristics. The advantage of this theory is that it has a more comprehensive approach. In an effort to develop career maturity Holland developed several tests that can help individuals to get to know themselves such as The Vocational Preference Inventory and Self-directed Search which asks for activities or activities they like, various competencies they have, areas of work they are interested in, and evaluations the self in some skills, must be matched with an occupational classification system based on the same theory, thus. young people can find a number of alternative occupational options for further consideration [7]. Holland also developed an Occupational Classification System that classifies 500 occupations in six occupational categories, namely: Realistic Occupations, Investigative Occupations, Artistic Occupations, Social Occupations, Entreprising Occupations, and Conventional Occupations. Holland [7] explains personality types can be divided into six types that are parallel with the work environment.

Descriptions of six personality categories using mnemonic Holland, called RIASEC (realistic, investigative, artistic, social, enterprising / business, and conventional). Following this RIASEC in the work environment and personality patterns include: 1) Realistic environment involves physical tasks that require mechanical skills, technical competence, perseverance, and physical movement. People in realistic environments have direct coping methods and handle pragmatic problems. Examples of the work of people with this orientation model are, machine/radio operators, truck drivers, farmers, pilots, building supervisors, electricians, and other similar work, 2) Investigation Environment This type of model has a tendency to choose jobs that are academic. This type requires the use of abstract and creative abilities. satisfactory performance demands intelligence and analytical skills. This work is with ideas and things rather than people.

Interaction between rational, analytical workers. and indirectly. Common settings include research laboratories, libraries, or work groups of scientists, mathematicians, or research engineers, 3) Artistic Environment requires creative use and interpretation of art forms. Workers draw on knowledge, intuition, and emotional life in solving typical problems. Information is assessed against aesthetics, subjective criteria. Work usually requires intense involvement for a long time. Typical settings include theater, concert halls, dance studios, libraries, and art or music studios, 4) The social environment requires the ability to interpret and modify human behavior and interests in caring for and dealing with others. The work often requires prolonged personal frequency and relationships, laden with emotional interaction, and flexibility. Common work situations include school and college classes, counseling offices, mental hospitals, churches, educational offices, and recreation centers, 5) Enterprising environment is a verbal ability to direct or persuade people. The job requires directing, controlling, or other planning activities, and social contact that is often and naturally friendly. Enterprising workers are confident and use speaking and setting typical leadership skills including many cars, real estate offices, political meetings, and advertising agencies, 6) The conventional environment involves a systematic, routine process of verbal and mathematical information. The task is often called for repetitive, short cycle operations carried out are often clerics in nature, which requires the use of offices according to established procedures. Work using equipment. Typical settings include a bank, an accounting firm, post office, file room, and business office.

The stages-stages of career development according to Dillard's theory are divided into four stages, namely the crystallization stage, the specification, the implementation phase, and the stabilization stage. Factors that can be considered in career maturity are how realistic individual choices are in relation to abilities, skills, interests, individual lifestyle, and available jobs. To make realistic career decisions in determining the future one should be able to develop mature attitudes and competent self-skills. A person's career occurs from the time of study, work and when someone retires.

According to Dillard, the achievement of one's career exploration maturity can be measured through five indicators, namely engaging in the career selection process, having orientation to work, having freedom in decision making, having the ability to consider a choice, and having a concept in choosing a career. Choosing a career is a process that extends over several years, starting from birth late in childhood and continuing into adulthood. The maturity of an individual's attitude in making career choices depends on how consistent individual career choices are over a certain period. Factors that can be considered in career maturity are how realistic individual choices are in relation to abilities, skills, interests, lifestyles, and available jobs. To make realistic career decisions in determining the direction of a good future one should be able to develop a mature attitude and competent self-skills. Remembering someone's career 
occurred from the time of study, work and when someone retires.

Furthermore according to Marcia \& Archer, high career exploration shows the depth of knowledge and understanding of adolescents about alternatives that exist in achieving identity, the assessment of adolescents regarding the criteria of choice desired and an assessment of the ability of self to make choices the said; conduct directed activities to gather information concerning all activities deemed appropriate for seeking and gathering the required information; able to consider the values of various information that has been held as possibilities and opportunities of each alternative that exists; showing pleasure, pride, and enthusiasm when digging up information about alternative choices in forming their identities; and the desire to make an early decision which is indicated by the extent to which the individual has the desire to resolve doubts or ambiguities as quickly as possible realistically and to believe what is considered right for him [8]. In line with the results of Kurniawan's study that cognitive abilities affect psychomotor abilities. Cognitive ability is closely related to psychomotor abilities, as evidenced by an obtained rxy of 0.73 included in the strong category [14].

The cognitive abilities of students gained through the learning process in class will equip students to carry out practice in the field. This means that the success of learning in the classroom will affect the success of practice in the field. Learning success in productive subjects can be seen from the values of student learning outcomes that include cognitive abilities, affective abilities and psychomotor abilities. In line with Rosa cognitive ability is one of the most important areas in the learning process [17]. Cognitive abilities consist of six stages namely memory, understanding, application, analysis, evaluation and creating. This includes the ability of students to understand a matter or learning material. Cognitive aspects include the process of remembering, understanding, applying, analyzing, evaluating, and creating or creating.

\section{CONCLUSION}

Career maturity is defined as an attitude in preparing a range of meaningful future work activities based on the personality characteristics of students through the process of developmental stages of high school students. Career maturity includes three aspects, namely cognitive aspects, affective aspects and psychomotor aspects. Indicators of cognitive aspects include understanding one's potential, considering values and analyzing career decision making.

Affective aspects are positive knowledge in the form of values and beliefs found in students. Indicators from the affective aspects include assessing, managing and living in career planning. Psychomotor aspects are the abilities possessed by students in the form of motor skills and physical abilities. Indicators from the psychomotor aspects include building self-motivation, operating facilities and infrastructure and managing career planning. Based on the results of the career maturity analysis that has been presented, it can be concluded that the career maturity profile of class XI high school students is a description of the career maturity of high school students based on the results of the test of career maturity instruments consisting of cognitive, affective and psychomotor aspects. The results showed that the general profile of career maturity is in the category of quite capable, the level of career maturity of the category of quite capable in this student means that the condition of the students of class XI high school now can be involved in building motivation to plan a career but have not been able to identify the potential that exists in student self optimally. in the psychomotor aspect, the highest percentage was $70 \%$. Then followed by affective aspects and psychomotor aspects.

\section{ACKNOWLEDGMENT}

In arranging this thesis, a lot of people have provided motivation, advice, and support for the researcher. In this valuable chance, the researcher intended to express his gratitude and appreciation to all of them. First, the researcher's deepest appreciation goes to my beloved parents. Also, this thesis would not have been possible without the help, support and patience of my first advisor for his supervision, advice, and guidance from the very early stage of this research as well as giving me extraordinary experiences throughout the past few years. Then to my second advisor who has helped me patiently finishing this undergraduate thesis by giving suggestion, guidance, and correction until the completion of this thesis. I gratefully thank to the principal of SMA N 6 Bandung for allowing me to conduct the research there. Finally, I would like to thank everybody who was important to the successful realization of this undergraduate thesis. This undergraduate thesis is far from perfect, but it is expected that it will be useful not only for the researcher, but also for the readers. For this reason, constructive thoughtfull suggestion and critics are welcomed.

\section{REFERENCES}

[1] Gonzalez, A. M. (2008). Career Maturity : a Priority for Secondary Education. Journal of Researching Educational Psychology. Departement of Educational Research and Diagnostics, 6 (3), 749-779.

[2] Sharf. R. (2006). Applying Career Development Theory (4th Ed). United States: Thomson Brooks/Cole.

[3] Aquila. (2012). Perbedaan Pengalaman Praktek Kerja Lapangan Pada Siswa SMA-SMK Dan Status Keputusan Karir Terhadap Kematangan Karir. Fakultas Psikologi Peminatan Psikologi Pendidikan Univeristas Indonesia.

[4] Watkins, C.E., \& Campbell, V.L. (2000). Testing and Assessment in Counseling Practice (2nd Ed.). Mahwah, NJ: Lawrence Erlbaum Associates.

[5] Saifudin, A., Ruhaena, L., Prastiti, D. (2017). Meningkatkan Kematangan Karir Peserta Didik SMA dengan Pelatihan Reach Your Dream dan Konseling Karir. Jurnal Psikologi, 44(1), 39-49.

[6] Dillard, John. (1985). Lifelong Career Planning. Columbus Ohio: A Bell \& Howell Company.

[7] Andersen, P., \& Vandehey, M. (2012). Career Counseling and Developtment in Global Economy (2 ${ }^{\text {nd }}$ edition). United States of America. Brooks/Cole Cengage Learning.

[8] Worthington, R.L, Flores, L.Y., \& Navarro, R.L. (2005). Career Development In Context: Research With People Of Color. In S.D. Brown \& R.W. Lent. Career Development And Counseling: Putting Theory And Research To Work (Pp. 225-252).

[9] Supriatna, M. (2010). Trend Problem Career in School. In Proceeding Seminar and Workshop Educational Psychology: Career Development in Psychology and Educational Perspective. Bandung. 
[10]Atmaja. (2014). Upaya Meningkatkan Perencanaan Karir Siswa Melalui Bimbingan Karir dengan Penggunaan Media Modul. Jurnal Psikopedagogia. Vol 3, No 2.

[11]Lestari, I. (2017). Meningkatkan Kematangan Karir Remaja Melalui Bimbingan Karir Berbasis Life Skill. Jurnal Konseling, 3

[12] Juwitaningrum, I. (2013). Progam Bimbingan Karir untuk Meningkatkan Kematangan Karir Siswa SMK. Jurnal Bimbingan dan Konseling, 2 (2).

[13]Nurlela. (2015). Efektivitas Konseling Karir Perkembangan Untuk Peningkatan Kematangan Karir Siswa Kelas XI SMA PGRI 2 Palembang Tahun ajaran 2014/2015. Tesis.

[14] Kurniawan, H. (2012). Pengaruh Kemampuan Kognitif Terhadap Kemampuan Psikomotorik Mata Pelajaran Produktif Alat Ukur Siswa
Kelas X Jurusan Teknik Kendaraan Ringan Di Smk Muhammadiyah Prambanan. Universitas Negeri Yogyakarta. Yogyakarta.

[15] Savickas, L.M. Porfeli, J.Erik. (2011). Revision of the Career Maturity Inventory : The Adaptability Form. Vol 19 (4) 355-374.

[16]Saifudin, A., Ruhaena, L., Prastiti, D. (2017). Meningkatkan Kematangan Karir Peserta Didik SMA dengan Pelatihan Reach Your Dream dan Konseling Karir. Jurnal Psikologi, 44(1), 39-49.

[17]Rosa, O, F. (2017). Eksplorasi Kemampuan Kognitif Siswa Terhadap Kemampuan Memprediksi, Mengobservasi Dan Menjelaskan Ditinjau Dari Gender. Jurnal Pendidikan Fisika Fakultas Muhammadiyah Metro.Vol.5,No.2. 